\title{
Optimized Atrazine Degradation by Pleurotus ostreatus INCQS 40310: an Alternative for Impact Reduction of Herbicides Used in Sugarcane Crops
}

Patrícia Maia Pereira ${ }^{1,2,3}$, Ricardo Sposina Sobral Teixeira ${ }^{3}$, Marcone Augusto Leal de Oliveira ${ }^{4}$, Manuela da Silva ${ }^{2}$ and Viridiana Santana Ferreira-Leitão ${ }^{1,3 *}$

${ }^{1}$ National Institute of Technology, Ministry of Science and Technology, Avenida Venezuela, 82, Rio de Janeiro, RJ 20081-312, Brazil

${ }^{2}$ FIOCRUZ-Postgraduate Program in Health Surveillance, National Institute for Health Quality Control, Oswaldo Cruz Foundation (Fiocruz), Avenida Brasil,

4365-Manguinhos, Rio de Janeiro, RJ 21040-900, Brazil

${ }^{3}$ Postgraduate Program in Biochemistry, Department of Biochemistry, Chemistry Institute, Federal University of Rio de Janeiro, Avenida Athos da Silveira Ramos, 149,

Cidade Universitaria, Rio de Janeiro, RJ 21941-909, Brazil

${ }^{4}$ Department of Chemistry, Federal University of Juiz de Fora, Juiz de Fora, MG 36036-330, Brazil

\begin{abstract}
The herbicide atrazine (2-chloro-4-ethylamine-6-isopropylamine-s-triazine) is extensively used for weed control in sugarcane crops. The application of fungi for the biodegradation of xenobiotics has been studied with promising results. Therefore, atrazine degradation mediated by Pleurotus ostreatus INCQS 40310 was evaluated, and the involvement of ligninolytic enzymes along with the degradation process was also investigated. To promote high degradation percentages and rates, a fractional factorial experimental design was first used to determine the most significant medium components for atrazine degradation. This strategy improved atrazine degradation from $39.0 \%$ to $71.0 \%$ after 15 days, with the formation of different metabolites. Afterward, a $3^{2}$ full factorial design was performed using the variables selected in the first part of this study. The salts $\mathrm{FeSO}_{4}$ and $\mathrm{MnSO}_{4}$ showed significant influence in the percentages and the rates of atrazine degradation. The medium optimization resulted in $90.3 \%$ and $94.5 \%$ of atrazine degradation after 10 days and 15 days, respectively. Although laccase activity was measured during the degradation process, it was not possible to correlate laccase activity with atrazine degradation. The results demonstrated the efficiency of $P$. ostreatus INCQS 40310 for atrazine degradation, thus demonstrating the potential of this fungus as a bioremediation agent.
\end{abstract}

Keywords: Pleurotus ostreatus; Atrazine; Herbicide degradation; Experimental design; Sugarcane herbicides

\section{Introduction}

Pesticides have been extensively applied in agriculture over the past 30 years, especially in Brazil, which has become one of the largest consumers of these xenobiotics, followed by Japan and the United States [1]. According to recent data and including formulated products [2], 725,000 tons of pesticides were commercialized in Brazil in 2009, $59 \%$ of which corresponded to herbicides ( 429,693 tons), followed by $21 \%$ insecticides and acaricides (150,189 tons), $12 \%$ fungicides $(89,889$ tons) and $8 \%$ categorized as other (55,806 tons).

In Brazil, the $2.9 \%$ expansion of sugarcane-cultivated areas from the $2011 / 2012$ harvest to the $2012 / 2013$ harvest [3] was accompanied by an increase in the consumption of specific inputs for the crop. This expansion has been motivated by a growing demand for ethanol, a fuel that plays a significant role in the Brazilian energy matrix.

As reported by de Armas et al. [4], herbicides comprise the most widely used class of pesticides in the cultivation of sugarcane. Moreover, $45 \%$ of the total world's production of herbicides corresponds to the triazine class [5]. The most often used triazine-class herbicide is atrazine (2-chloro-4-ethylamine-6-isopropylamine-s-triazine), which is generally applied to control weeds during pre- or post-emergence, especially in sugarcane-, corn- and soybean-cultivated areas [5]. The chemical structure of atrazine is represented by a triazine ring that has been substituted with chlorine, ethylamine and isopropylamine, the combination of which makes it recalcitrant to biological degradation in the environment [6].

Atrazine has low solubility in water $\left(33 \mathrm{mg} \mathrm{L}^{-1}\right.$ at $\left.27^{\circ} \mathrm{C}\right)$. However, it is soluble in many organic solvents ( 360 to $183,000 \mathrm{mg} \mathrm{L}^{-1}$ ), such as acetonitrile and methanol [7]. Due to its low partition coefficient (octanolwater), it is not significantly adsorbed by soil. Hence, it is often found above the tolerable levels recommended by environmental agencies in surface water and groundwater [4]. The United States Environmental Protection Agency and the World Health Organization established limits of $2 \mu \mathrm{g} / \mathrm{L}$ and $3 \mu \mathrm{g} / \mathrm{L}$ of atrazine in drinking water, respectively [8]. The degradation and mineralization of atrazine can occur through physical-chemical processes or by microorganism action. Previous studies reported in the literature have identified more than 15 metabolites resulting from atrazine degradation [9-13]. The main atrazine degradation products are hydroxylated and chlorinated compounds, including desethylatrazine (2-chloro-4-amino-6-isopropylamine-s-triazine, DEA), desisopropylatrazine (2-chloro-4-ethylamine-6-aminos-triazine, DIA), desethyldesisopropylatrazine (2-chloro-4,6-aminos-triazine, DEDIA), desethylhydroxyatrazine (2-hydroxy-4-amino6-isopropylamine-s-triazine, DEHA), desisopropylhydroxyatrazine (2-hydroxy-4-ethylamine-6-amino-s-triazine, DIHA) and hydroxyatrazine (2-hydroxy-4-ethylamine-6-isopropylamine-s-triazine, HA).

Bioremediation explores the genetic diversity and metabolic versatility of microorganisms and has been a very promising approach to convert environmental contaminants into less toxic products that

*Corresponding author: Viridiana Santana Ferreira-Leitão, National Institute of Technology, Ministry of Science and Technology, Av. Venezuela 82, 302 CentroCEP 20081-312 Rio de Janeiro - RJ - Brazil, Tel: +55 21-2123-1108/1109; Fax: +55 21-2123-1166; E-mail: viridiana.leitao@int.gov.br

Received April 03, 2013; Accepted May 03, 2013; Published May 06, 2013

Citation: Pereira PM, Sobral Teixeira RS, de Oliveira MAL, da Silva M, FerreiraLeitão VS (2013) Optimized Atrazine Degradation by Pleurotus ostreatus INCQS 40310: an Alternative for Impact Reduction of Herbicides Used in Sugarcane Crops. J Microb Biochem Technol S12: 006. doi:10.4172/1948-5948.S12-006

Copyright: (c) 2013 Pereira PM, et al. This is an open-access article distributed under the terms of the Creative Commons Attribution License, which permits unrestricted use, distribution, and reproduction in any medium, provided the original author and source are credited 
Citation: Pereira PM, Sobral Teixeira RS, de Oliveira MAL, da Silva M, Ferreira-Leitão VS (2013) Optimized Atrazine Degradation by Pleurotus ostreatus INCQS 40310: an Alternative for Impact Reduction of Herbicides Used in Sugarcane Crops. J Microb Biochem Technol S12: 006. doi:10.4172/1948-5948.S12-006

can be integrated into natural biogeochemical cycles [14]. Within the soil, the degradation of atrazine by fungi usually follows pathways that involve the sequential removal of the aromatic ring substituents, beginning with dealkylation, which is the first step in the degradation of this compound $[12,15]$. The application of fungi for the biodegradation of recalcitrant chemicals has been widely studied [16-20]. This interest is based on the fungal capacity to degrade several molecules of organic pollutants and other persistent toxic substances using nonspecific enzymes [21-26]. Basidiomycetes, including the genus Pleurotus, can degrade lignocellulosic materials through extracellular ligninolytic enzymes, such as laccase, manganese peroxidase and lignin peroxidase. The oxidative activity and the low specificity of this enzymatic pool are generally responsible for the degradation of recalcitrant organic pollutants [27], which makes these enzymes important catalysts for environmental applications. In addition, previous studies with the white-rot fungus Phanerochaete chrysosporium also indicated the degradation of atrazine by P450 enzymes [15,28]

The purpose of this work was to apply an experimental design as a tool to improve atrazine degradation that is mediated by the well-known fungus Pleurotus ostreatus. This optimization strategy of promoting the increase of atrazine degradation aims to present a promising alternative for the degradation of sugarcane herbicides.

\section{Materials and Methods}

\section{Fungus and culture media}

The fungus $P$. ostreatus INCQS 40310 was kindly provided by the Federal University of Lavras and deposited in the Collection of Reference Microorganisms in Health Surveillance (Fiocruz-CMRVS). $P$. ostreatus INCQS 40310 was grown on potato dextrose agar (PDA) medium for 7 days and preserved at $4^{\circ} \mathrm{C}$ prior to freezing in glycerol at $-70^{\circ} \mathrm{C}$. The fungus $P$. ostreatus INCQS 40310 was selected from a previous study on atrazine tolerance [29]

For the initial atrazine degradation experiments, a basic nutrient medium at $\mathrm{pH} 6.0$ was used, as previously described by Gorbatova et al. [30].

\section{Atrazine degradation experiments}

P. ostreatus INCQS 40310 was inoculated into PDA. After inoculation, the agar plates were incubated at $28^{\circ} \mathrm{C}$. After 7 days of incubation, 3 mycelial plugs ( $5 \mathrm{~mm}$ diameter) from the colony margin were used as an inoculum. The mycelial plugs were transferred to conical flasks containing $300 \mathrm{~mL}$ of basic nutrient medium and atrazine at a final concentration of $10 \mathrm{mg} \mathrm{L}^{-1}$. The degradation studies were performed in triplicate; therefore, 3 flasks for each condition studied were incubated while agitating at $200 \mathrm{rpm}$ for 20 days at $28^{\circ} \mathrm{C}$ $\pm 2^{\circ} \mathrm{C}$. Samples of $3 \mathrm{~mL}$ were collected from each flask every 5 days of incubation and extracted on Waters Oasis MCX cartridges (a cationexchange resin extraction). Atrazine and its derivatives were analyzed by high-performance liquid chromatography (HPLC). Control experiments were performed under the same conditions in the absence of the P. ostreatus INCQS 40310 or atrazine, as described above.

\section{High-performance liquid chromatography analyses}

After solid-phase extraction, the extracts were analyzed by HPLC using a Shimadzu LC-10AT chromatograph that was equipped with a UV-Vis detector, which was monitored at $221 \mathrm{~nm}$ and $230 \mathrm{~nm}$. The flow was kept at $1 \mathrm{~mL} / \mathrm{min}$, the auto-injection volume was $20.0 \mu \mathrm{L}$ and a Class VP 6.1 program was used for data acquisition and system control. The HPLC column used was a Shim-Pack C18 $(250 \times 4.6 \mathrm{~mm}$, $4.6 \mu \mathrm{m})$, and the mobile phases were composed of ACN and phosphate buffer, pH 7.2, using a segmented gradient elution [29]. The atrazine degradation and product formation were analyzed by HPLC under the same conditions, as previously described. The standards of A (purity 98.4\% w/w) and its derivatives, DIA (purity $98.0 \% \mathrm{w} / \mathrm{w}$ ), DEA (purity 98.5\% w/w), HA (purity $96.0 \% \mathrm{w} / \mathrm{w}$ ) and DEDIA (purity $95.7 \% \mathrm{w} / \mathrm{w}$ ); were obtained from Dr. Ehrenstorfer GmbH company. DEHA (purity 98.7\% w/w) and DIHA (purity $98.0 \% \mathrm{w} / \mathrm{w}$ ) were obtained from Riedel Company-de-Haën. All solutions were stored in a freezer.

\section{Maximizing the degradation of atrazine through experimental design}

To attain the optimum culture medium composition for the atrazine degradation, a factorial experimental design was used to evaluate the significance of each of the components. Physical variables, such as agitation speed, temperature, $\mathrm{pH}$ and incubation time, were not considered for the statistical design analysis. These conditions were selected from previous studies reported in the literature, as culture medium components have been demonstrated by Teixeira and coworkers to be more relevant than physical variables [20].

It is important to study the actual effects of each compound in the medium and to also minimize the amount of each component to reduce costs. The $2_{\text {IV }}{ }^{8-4}$ fractional factorial design was initially employed to investigate the main effects and their interactions with the factors on the percentage of atrazine degradation. In the first stage of the study, the concentration of salts was equal to zero. The following independent variables were tested: $\left(\mathrm{X}_{1}\right)$ zinc sulfate, $\left(\mathrm{X}_{2}\right)$ iron sulfate, $\left(\mathrm{X}_{3}\right)$ manganese sulfate, $\left(\mathrm{X}_{4}\right)$ magnesium sulfate, $\left(\mathrm{X}_{5}\right)$ copper sulfate, $\left(\mathrm{X}_{6}\right)$ glucose, $\left(\mathrm{X}_{7}\right)$ peptone, and $\left(\mathrm{X}_{8}\right)$ yeast extract. All these factors were evaluated at two levels, low $(-1)$ and high $(+1)$, which were combined according to a $2^{8-}$ ${ }^{4}$ fractional factorial design (resolution four), with 4 repetitions at the central point ( 0 ) and generating relationships $\mathrm{I}=1235, \mathrm{I}=1246, \mathrm{I}=1347$ and $\mathrm{I}=2348$. Subsequently, the $3^{2}$ full factorial design was used for the optimization of the microbial process for atrazine degradation. The monitored responses were the degradation of atrazine (expressed as percentage) and laccase enzyme activity (expressed in UI $\mathrm{mL}^{-1}$ ). Based on factorial design, samples were collected at 5, 10, 15 and 20 days of incubation and processed as described above during the experiments of atrazine degradation.

\section{Software}

In the present study, the software Statistica 7.0 (StatSoft, Tulsa, OK, USA) was used for the design of the experiment and analysis of the obtained data.

\section{Determination of enzymatic activities}

The presence and involvement of ligninolytic enzymes produced by $P$. ostreatus INCQS 40310 was also investigated. Laccase activity was determined spectrophotometrically according to the method of Niku-Paavola et al. [31] with slight modifications by monitoring the oxidation of 2,2'-azino-bis(3-ethylbenzothiazoline-6-sulfonic acid)ABTS at room temperature without agitation. The assay mixture contained $3 \mathrm{mM}$ ABTS, $0.2 \mathrm{M}$ sodium succinate buffer ( $\mathrm{pH} 4.5)$ and $100 \mu \mathrm{L}$ of reaction medium in a total volume of $2 \mathrm{~mL}$. The oxidation of ABTS was monitored at $420 \mathrm{~nm}\left(\varepsilon=36,000 \mathrm{M}^{-1} \mathrm{~cm}^{-1}\right)$.

Manganese peroxidase activity was determined spectrophotometrically according to the oxidation of phenol red in the presence of manganese and hydrogen peroxide [32]. The assay mixture 
Citation: Pereira PM, Sobral Teixeira RS, de Oliveira MAL, da Silva M, Ferreira-Leitão VS (2013) Optimized Atrazine Degradation by Pleurotus ostreatus INCQS 40310: an Alternative for Impact Reduction of Herbicides Used in Sugarcane Crops. J Microb Biochem Technol S12: 006. doi:10.4172/1948-5948.S12-006

Page 3 of 8

contained $0.25 \mathrm{mM}$ sodium lactate, $0.5 \%$ bovine albumin, $2 \mathrm{mM}$ $\mathrm{MnSO}_{4}, 500 \mu \mathrm{L}$ of the reaction medium, $0.1 \%$ phenol red and $2 \mathrm{mM}$ $\mathrm{H}_{2} \mathrm{O}_{2}$. The oxidation of phenol red was monitored at $610 \mathrm{~nm}(\varepsilon=44,600$ $\left.\mathrm{M}^{-1} \mathrm{~cm}^{-1}\right)$.

Lignin peroxidase activity was determined spectrophotometrically according to the oxidation of veratryl alcohol into veratryl aldehyde [33]. The assay mixture contained $50 \mathrm{mM}$ sodium tartrate buffer, 50 $\mathrm{mM}$ veratryl alcohol, $1800 \mu \mathrm{L}$ of the reaction medium and $10 \mathrm{mM}$ $\mathrm{H}_{2} \mathrm{O}_{2}$. The oxidation of veratryl alcohol was monitored at $310 \mathrm{~nm}$ $\left(\varepsilon=9,200 \mathrm{M}^{-1} \mathrm{~cm}^{-1}\right)$.

\section{Results and Discussion}

\section{Optimization of atrazine degradation through factorial design}

Twenty assays were performed with different concentrations of each component of the culture medium to determine optimal conditions for the maximum degradation of atrazine, according to the data shown in table 1 . The changes in the concentrations of the components in the culture medium promoted an increase in the percentage of atrazine degradation and the diversification of the metabolites formed.

Different results were obtained according to the compositions of the culture medium, revealing that the highest percentage of atrazine degradation occurred in assay 12 in which $71 \%$ of atrazine was transformed after 15 days. Moreover, after 10 days of cultivation, less than $50 \%$ of the atrazine had been consumed. It should also be noted that the maximum atrazine degradation was $39.0 \%$ prior to the factorial design [29].
The use of this statistical tool proved to be very efficient because it increased atrazine degradation by 1.8 times and diversified the metabolites that were formed. In addition to DEA and DIA, the metabolites DIHA, DEDIA and DEHA were also detected (Table 2).

According to the literature, atrazine is more toxic than its degradation products [34]. For example, atrazine presented higher chronic toxicity when compared to DEA towards rat endocrine activity. The degradation product DEDIA was also less toxic than s-triazine (the ring system of triazine) towards birds. For phototrophic microorganisms, the decreasing order of toxicity was: atrazine $>$ DEA $>$ DIA. Additionally, the degradation products $\mathrm{HA}$ and DEDIA were nontoxic towards most phototrophic microorganism cultures tested [35]. The herbicide atrazine was partly converted into polar dechlorinated and/or N-dealkylated metabolites. These results agreed with previous studies described in the literature [15] in which the dealkylated products appeared as the major metabolites during the microbial degradation of chloro-s-triazines. In general, soil fungi remove the ethyl group of atrazine before the removal of the isopropyl group [36,37].

Table 2 presents the most relevant results obtained from the fractional factorial design $\left(2_{\mathrm{IV}}^{8-4}\right)$, regarding not only the optimal percentage of degradation $(4,11,12)$ but also the results that showed minimum medium composition (1) and unidentified metabolites $(13,16)$. Another interesting result was obtained from assay 4 , which promoted $60 \%$ atrazine degradation after 20 days with the formation of DIHA, DEDIA, DIA, HA and DEA.

Even though the atrazine degradation in assay 1 achieved only $38 \%$ after 10 days, this result should be emphasized because the culture

\begin{tabular}{|c|c|c|c|c|c|c|c|c|c|c|c|c|}
\hline \multirow{2}{*}{ Assays } & \multicolumn{8}{|c|}{ Contrast coefficients } & \multicolumn{4}{|c|}{ Atrazine degradation (\%) } \\
\hline & $\mathrm{x}_{1}$ & $\mathrm{X}_{2}$ & $\mathbf{X}_{3}$ & $X_{4}$ & $X_{5}$ & $x_{6}$ & $x_{7}$ & $\mathrm{X}_{8}$ & 5 days & 10 days & 15 days & 20 days \\
\hline 1 & -1 & -1 & -1 & -1 & -1 & -1 & -1 & -1 & 8.5 & 38.5 & 38.8 & 33.5 \\
\hline 2 & 1 & -1 & -1 & -1 & 1 & 1 & 1 & -1 & 11.6 & 21.5 & 16.0 & 21.5 \\
\hline 3 & -1 & 1 & -1 & -1 & 1 & 1 & -1 & 1 & 15.5 & 23.2 & 22.2 & 23.7 \\
\hline 4 & 1 & 1 & -1 & -1 & -1 & -1 & 1 & 1 & 22.6 & 31.7 & 49.7 & 59.7 \\
\hline 5 & -1 & -1 & 1 & -1 & 1 & -1 & 1 & 1 & 23.2 & 24.4 & 43.3 & 49.4 \\
\hline 6 & 1 & -1 & 1 & -1 & -1 & 1 & -1 & 1 & 19.4 & 23.3 & 21.0 & 33.1 \\
\hline 7 & -1 & 1 & 1 & -1 & -1 & 1 & 1 & -1 & 32.5 & 34.6 & 35.7 & 31.5 \\
\hline 8 & 1 & 1 & 1 & -1 & 1 & -1 & -1 & -1 & 22.0 & 38.2 & 39.8 & 28.9 \\
\hline 9 & -1 & -1 & -1 & 1 & -1 & 1 & 1 & 1 & 6.8 & 16.3 & 18.7 & 18.7 \\
\hline 10 & 1 & -1 & -1 & 1 & 1 & -1 & -1 & 1 & 14.3 & 19.0 & 36.1 & 37.1 \\
\hline 11 & -1 & 1 & -1 & 1 & 1 & -1 & 1 & -1 & 23.6 & 36.5 & 52.1 & 63.3 \\
\hline 12 & 1 & 1 & -1 & 1 & -1 & 1 & -1 & -1 & 4.9 & 52.5 & 71.0 & 71.0 \\
\hline 13 & -1 & -1 & 1 & 1 & 1 & 1 & -1 & -1 & 21.4 & 25.1 & 34.9 & 35.7 \\
\hline 14 & 1 & -1 & 1 & 1 & -1 & -1 & 1 & -1 & 5.1 & 5.7 & 8.9 & 6.3 \\
\hline 15 & -1 & 1 & 1 & 1 & -1 & -1 & -1 & 1 & 24.0 & 26.6 & 33.0 & 32.2 \\
\hline 16 & 1 & 1 & 1 & 1 & 1 & 1 & 1 & 1 & 15.4 & 18.2 & 22.9 & 23.9 \\
\hline 17 & 0 & 0 & 0 & 0 & 0 & 0 & 0 & 0 & 15.0 & 19.9 & 20.1 & 26.0 \\
\hline 18 & 0 & 0 & 0 & 0 & 0 & 0 & 0 & 0 & 21.6 & 24.9 & 25.9 & 38.5 \\
\hline 19 & 0 & 0 & 0 & 0 & 0 & 0 & 0 & 0 & 23.5 & 26.9 & 28.1 & 23.6 \\
\hline 20 & 0 & 0 & 0 & 0 & 0 & 0 & 0 & 0 & 16.0 & 19.6 & 18.1 & 24.8 \\
\hline
\end{tabular}

$\left.\mathrm{X}_{1}-\mathrm{ZnSO}_{(\mathrm{g} \mathrm{L}} \mathrm{L}^{-1}\right):(-1): 0.0,(0): 0.001,(+1): 0.002$

$\mathrm{X}_{2}-\mathrm{FeSO}_{4}:\left(\mathrm{g} \mathrm{L}^{-1}\right)(-1): 0.0,(0): 0.0005,(+1): 0.001$

$\mathrm{X}_{3}-\mathrm{MnSO}_{4}\left(\mathrm{~g} \mathrm{~L}^{-1}\right):(-1): 0.0,(0): 0.05,(+1): 0.1$

$\mathrm{X}_{4}-\mathrm{MgSO}_{4}\left(\mathrm{~g} \mathrm{~L}^{-1}\right):(-1): 0.0,(0): 0.5,(+1): 1.0$

$\mathrm{X}_{5}-\mathrm{CuSO}_{4}\left(\mathrm{~g} \mathrm{~L}^{-1}\right):(-1): 0.0,(0): 0.25,(+1): 0.5$

$\mathrm{X}_{6}$ - glucose $\left(\mathrm{g} \mathrm{L}^{-1}\right):(-1): 2.0,(0): 5.0,(+1): 8.0$

$X_{7}^{6}$ - peptone $\left(g^{-1}\right):(-1): 1.0,(0): 3.0,(+1): 5.0$

$\mathrm{X}_{8}$ - yeast extract $\left(\mathrm{g} \mathrm{L}^{-1}\right):(-1): 2.0,(0): 5.0,(+1): 8.0$

Table 1: Fractional factional design $2{ }_{\mathrm{IV}}{ }^{8-4}$ with encoded variables and atrazine degradation. 
Citation: Pereira PM, Sobral Teixeira RS, de Oliveira MAL, da Silva M, Ferreira-Leitão VS (2013) Optimized Atrazine Degradation by Pleurotus ostreatus INCQS 40310: an Alternative for Impact Reduction of Herbicides Used in Sugarcane Crops. J Microb Biochem Technol S12: 006. doi:10.4172/1948-5948.S12-006

Page 4 of 8

medium from this assay contained the poorest medium composition established in the factorial design, level-1, as described in table 1. Therefore, considering the lowest concentration of constituents and also the absence of all salts, it is noteworthy that conditions in assay 1 simulated the low-cost medium composition in this study.

The results obtained after the fractional factorial design $\left(2_{\mathrm{IV}}^{8}\right.$ $\left.{ }^{4}\right)$ presented certain advantages, as mentioned above, including an increased level of degradation, medium composition reduction and diversification of the degradation products.

The first part of this study revealed the significance of the variables analyzed. Considering the results obtained from the $2^{8-4}$ fractional factorial design (Table 1), only the variables $\mathrm{X}_{2}\left(\mathrm{FeSO}_{4}\right)$ and $\mathrm{X}_{3}\left(\mathrm{MnSO}_{4}\right)$ were significant within the $95 \%$ confidence interval for atrazine degradation (\%) during the first 15 days. The other variables were not significant within the intervals investigated, according to the Pareto chart (data not shown). Regarding the Pareto chart, the effect bars that crossed the red dashed line were significant within the 95\% interval. Additionally, $\mathrm{FeSO}_{4}$ exhibited a positive significant effect, while $\mathrm{MnSO}_{4}$ had a negative effect. The other variables were not significant within the concentration interval investigated. Thus, considering the results obtained from the $2_{\mathrm{IV}}{ }^{8-4}$ fractional factorial design and to improve the atrazine degradation, the concentration of no significant variables were maintained at low levels (-1), i.e., $\mathrm{ZnSO}_{4}=0 \mathrm{~g} \mathrm{~L}^{-1}, \mathrm{MgSO}_{4}=0 \mathrm{~g} \mathrm{~L}^{-1}$, $\mathrm{CuSO}_{4}=0 \mathrm{~g} \mathrm{~L}^{-1}$, glucose $=2 \mathrm{~g} \mathrm{~L}^{-1}$, peptone $=1 \mathrm{~g} \mathrm{~L}^{-1}$ and yeast extract $=2$ $\mathrm{g} \mathrm{L}^{-1}$. A $3^{2}$ full factorial design with triplicate at the central point was then performed, considering just the variables $\mathrm{FeSO}_{4}$ and $\mathrm{MnSO}_{4}$. The studied concentration range of $\mathrm{FeSO}_{4}$ was increased, while $\mathrm{MnSO}_{4}$ was decreased based on the $2_{\mathrm{IV}}{ }^{8-4}$ fractional factorial design results, as shown in table 3.

Presented in table 3 , the results obtained from the $3^{2}$ full factorial design showed that the percentages of atrazine degradation were only as high as $4.1 \%$ among the 11 experiments performed after 5 days of incubation. However, after 10 and 15 days, the results were significant. Experiments 3, 8, 9, 10 and 11 were very similar for the period of 10 and 15 days, presenting atrazine degradation percentages of approximately $80 \%$. Less favorable conditions were observed for atrazine degradation after 10 and 15 days when the concentrations of $\mathrm{FeSO}_{4}$ and $\mathrm{MnSO}_{4}$ were simultaneously maintained at the lowest level (77\%, assay 1$)$. However, the best results obtained simultaneously for the period of 10 (90.3\%) and 15 days (94.5\%) were observed when $\mathrm{FeSO}_{4}$ and $\mathrm{MnSO}_{4}$ were fixed at low and high levels, respectively (assay 7). Therefore, assay 7 showed the best results from this optimization study. In addition to maximizing the atrazine degradation level, which reached $90.3 \%$ within 10 days of incubation, it also allowed a 5 day reduction in incubation time. Very good results were also obtained with assays 5, 6 and 7 in which the atrazine degradation was greater than $90 \%$ after 15 days. It should also be noted that all the assays showed good percentages of atrazine degradation, which varied from $77 \%$ to $95 \%$ after 15 days of incubation. The period of 15 days presented the best set of results for the percentage of atrazine degradation. As a matter of fact, the 15 day period did not show a lack of fit for the model:

$\mathrm{y}^{\prime}=88.94( \pm 2.20)+0.12( \pm 1.74) \mathrm{X} 1+2.77( \pm 1.74) \mathrm{X} 2-1.02( \pm 2.70)$ $\mathrm{X} 12-2.40( \pm 2.70) \mathrm{X} 22-4.16( \pm 2.13) \mathrm{X} 1 \mathrm{X} 2$

within a $95 \%$ confidence interval, as the lack of fit test returned $\mathrm{F}_{\text {calculated }}$ (mean square ${ }_{\text {lack of fit }} /$ mean Square $\left.{ }_{\text {pure error }}\right)=1.03$, which was less than $\mathrm{F}_{\text {critical,n1:3,n2:3,a:0.05 }}$ 19.16. This result was corroborated by the corresponding response surface plot, which describes the atrazine degradation percentage for the system studied. It is important to highlight that no model coefficients were significant for a equal to 0.05 (Figure 1).

The sequential strategy enabled the selection of a culture medium that was capable of promoting high atrazine degradation $(90.3 \%$ and $94.5 \%$ ) after 10 and 15 days, respectively. Table 4 clearly shows that, in addition to DEA and DIA, which were previously produced, DIHA, DEDIA and DEHA were also obtained. This result revealed the

\begin{tabular}{|c|c|c|c|}
\hline Assays & Degradation (\%) & Time (days) & Metabolites Formed \\
\hline 1 & 38.8 & 10 & DIA, DEA \\
\hline 4 & 59.7 & 20 & DIHA, DEDIA, DIA, HA, DEA \\
\hline 11 & 63.3 & 20 & DIA \\
\hline 12 & $\mathbf{7 1 . 0}$ & $\mathbf{1 5}$ & DIHA, DEDIA, DEHA, DIA, DEA $^{*}$ \\
\hline 13 & 35.7 & 15 & DIA, HA, DEA, U.M. \\
\hline 16 & 24.8 & 15 & DEHA, DEA, U.M. ${ }^{*}$ \\
\hline
\end{tabular}

*U.M. - unidentified metabolites

Table 2: Percentage of atrazine degradation and its metabolites formed for the most relevant results after the fractional factorial design $\left(2_{\mathrm{IV}}^{8-4}\right)$. The best result assay 12 , is highlighted.

\begin{tabular}{|c|c|c|c|c|c|}
\hline \multirow{2}{*}{ Assays } & \multirow{2}{*}{ Contrast coefficients $\mathbf{X}_{\mathbf{1}}$} & \multirow{2}{*}{$\mathbf{X}_{\mathbf{2}}$} & \multicolumn{3}{|c|}{ Atrazine degradation (\%) } \\
\hline & & $\mathbf{5}$ days & $\mathbf{1 0}$ days & $\mathbf{1 5}$ days \\
\hline 1 & -1 & -1 & 3.2 & 46.9 & 77.1 \\
\hline 2 & 0 & -1 & 4.1 & 48.5 & 88.4 \\
\hline 3 & 1 & -1 & 2.2 & 82.5 & 83.7 \\
\hline 4 & -1 & 0 & 2.9 & 48.7 & 86.9 \\
\hline 5 & 0 & 0 & 3.6 & 82.6 & 93.0 \\
\hline 6 & 1 & 0 & 2.4 & 72.7 & 91.1 \\
\hline 7 & -1 & 1 & 3.9 & 90.3 & 94.5 \\
\hline 8 & 0 & 1 & 2.6 & 84.4 & 86.9 \\
\hline 9 & 1 & 1 & 2.9 & 83.6 & 84.5 \\
\hline 10 & 0 & 0 & 3.8 & 85.8 & 86.9 \\
\hline 11 & 0 & 0 & 4.1 & 80.5 & 84.8 \\
\hline
\end{tabular}

$\mathrm{X}_{1}-\mathrm{FeSO}_{4}\left(\mathrm{~g} \mathrm{~L}^{-1}\right):(-1): 0.001 ;(0): 0.0015 ;(+1): 0.002$

$\mathrm{X}_{2}-\mathrm{MnSO}_{4}\left(\mathrm{~g} \mathrm{~L}^{-1}\right):(-1): 0.0(0): 0.025 ;(+1): 0.05$

Table 3: Experimental design $\left(3^{2}\right)$ with encoded variables and atrazine degradation.

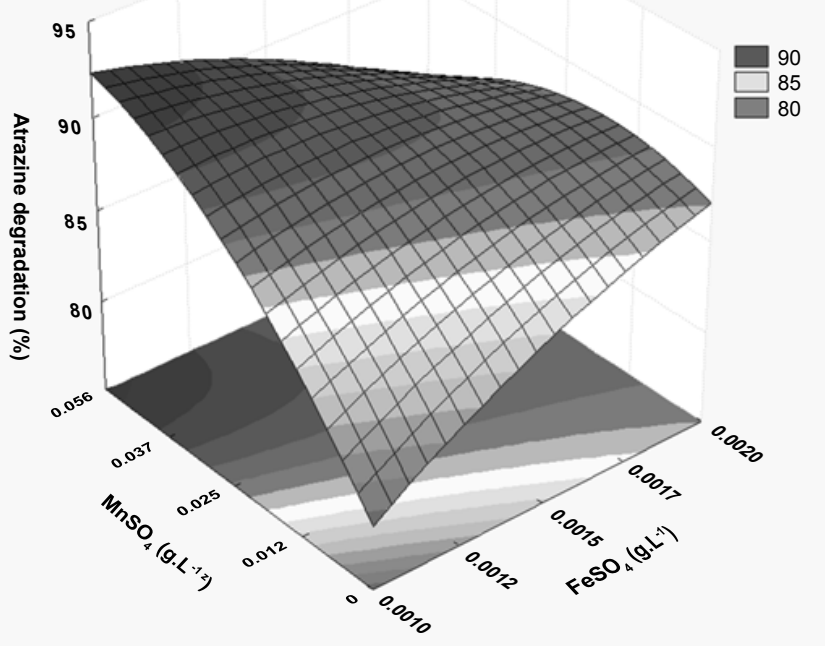

Figure 1: Response surface of atrazine degradation as a function of $\mathrm{FeSO}_{4}$ and $\mathrm{MnSO}_{4}$ concentrations. 
Citation: Pereira PM, Sobral Teixeira RS, de Oliveira MAL, da Silva M, Ferreira-Leitão VS (2013) Optimized Atrazine Degradation by Pleurotus ostreatus INCQS 40310: an Alternative for Impact Reduction of Herbicides Used in Sugarcane Crops. J Microb Biochem Technol S12: 006. doi:10.4172/1948-5948.S12-006

Page 5 of 8

relevance of the adopted strategy, as it allowed the diversification of the metabolites and a reduction in both the number and the concentrations of the components of the culture medium.

Compared to previous studies [15,28,38,39], the results obtained in the two stages of the experimental design (assay 12 and assay 7) of the current investigation were far superior (Table 5)

\section{Determination of laccase activities}

In the present study, the correlation between the ligninolytic enzymes and the atrazine degradation was also evaluated. The fungus $P$. ostreatus is widely known for its capacity to secrete several ligninolytic enzymes [40]. Laccase, lignin peroxidase and manganese peroxidase were evaluated during this optimization study; however, only very low laccase activity was determined, as $\mathrm{LiP}$ and $\mathrm{MnP}$ activities were not detected. Moreover, the laccase activity pattern revealed very similar behaviors both in the presence and absence of atrazine, which indicated that atrazine did not act as an inducer of the laccase production (data not shown).

Figure 2 shows the activity of laccase over 20 days in the $2_{\mathrm{IV}}^{8-4}$ fractional factorial design, and Figure 3 shows the activity of laccase obtained from the $3^{2}$ full factorial design.

From the fractional factorial design (Figure 2), the highest laccase activity was obtained in assay $11\left(1.4 \mathrm{UI} \mathrm{mL}^{-1}\right)$, which exhibited $63 \%$ atrazine degradation after 20 days, while the highest percentage of atrazine degradation was found in assay 12 (71\% after 15 days) (Table
2). Although it was not possible to correlate the laccase activity with the atrazine degradation, the medium from assay 11 tripled the production of laccase when compared with the results obtained before the experimental design $\left(0.533 \mathrm{UI} \mathrm{mL}^{-1}\right)$. Assay 12 , which showed the highest level of atrazine degradation, presented a non-significant laccase activity of $0.174 \mathrm{UI} \mathrm{mL}^{-1}$ after 10 days (Figure 2). Similar results were found in the $3^{2}$ full factorial design, indicating low activity of laccase in assay 7 (highest percentage of atrazine degradation).

The literature also reported studies from which there was no correlation between pesticide degradation and ligninolytic enzymes, corroborating the present results. Hiratsuka et al. [41] demonstrated that Trametes versicolor IFO 30340 was able to degrade a series of diphenyl ether herbicides without the involvement of ligninolytic enzymes. However, intracellular enzymes, such as cytochrome P450 monooxygenases, were responsible for mediating the initial $\mathrm{N}$-dealkylation of the herbicide. The involvement of the P450 enzymes in atrazine degradation was also studied in the presence of the whiterot fungus $P$. ostreatus $[15,28]$.

Bastos and Magan [42] studied the degradation of the herbicide atrazine in soil by the fungus Trametes versi color over 24 weeks and found that the enzyme laccase played an insignificant role in the degradation process, which corroborates the findings of the current investigation.

The aforementioned results and the previous studies reported in the literature support the choice of $P$. ostreatus INCQS 40310 for

\begin{tabular}{|c|c|c|c|c|}
\hline Conditions studied & \multicolumn{2}{|c|}{ Culture medium Composition ( $\mathrm{g} \mathrm{L}^{-1}$ ) } & Pergentage of degradation after 10 days & Pergentage of degradation after 15 days \\
\hline Initial Condition [30] & $\begin{array}{l}\mathrm{ZnSO}_{4} \\
\mathrm{FeSO}_{4} \\
\mathrm{MnSO}_{4} \\
\mathrm{MgSO}_{4} \\
\mathrm{CuSO}_{4} \\
\mathrm{Glucose} \\
\text { Peptone } \\
\text { Yeast Extract }\end{array}$ & $\begin{array}{c}(0.001) \\
(0.0005) \\
(0.05) \\
(0.5) \\
(0.25) \\
(5.0) \\
(3.0) \\
(5.0)\end{array}$ & 22.8 & 39.0 \\
\hline $\begin{array}{l}\text { Fractional factorial design }\left(2_{\mathrm{IV}}^{8-4}\right) \\
\quad(\text { Best condition - assay } 12)\end{array}$ & $\begin{array}{l}\mathrm{ZnSO}_{4} \\
\mathrm{FeSO}_{4} \\
\mathrm{MgSO}_{4} \\
\text { Glucose } \\
\text { Peptone } \\
\text { Yeast Extractt }\end{array}$ & $\begin{array}{c}(0.002) \\
(0.001) \\
(1.0) \\
(8.0) \\
(1.0) \\
(2.0)\end{array}$ & 52.5 & 71.0 \\
\hline $\begin{array}{l}\text { Full experimental design }\left(3^{2}\right) \\
\text { (Best condition - assay } 7 \text { ) }\end{array}$ & $\begin{array}{l}\mathrm{FeSO}_{4} \\
\mathrm{MnSO}_{4} \\
\mathrm{Glucose} \\
\text { Peptone } \\
\text { Yeast Extract }\end{array}$ & $\begin{array}{c}(0.001) \\
(0.05) \\
(2.0) \\
(1.0) \\
(2.0)\end{array}$ & 90.3 & 94.5 \\
\hline
\end{tabular}

Table 4: Comparative analyses of culture media composition before and after the experimental design. The best results of atrazine degradation were also given.

\begin{tabular}{|c|c|c|c|c|c|}
\hline Fungi & Time (days) & Concentration & Metabolites formed & Degradation (\%) & Reference \\
\hline $\begin{array}{l}\text { Phanerochaete crhysosporium } \\
\text { BKM-F-1767 }\end{array}$ & 16 & $2 \mu \mathrm{m} \mathrm{L}^{-1}$ & HA, DEA, DEHA and DIA & 48 & [15] \\
\hline Pleurotus ostreatus & 42 & $10 \mathrm{mg} \mathrm{L}^{-1}$ & U.M. ${ }^{*}$ & 15,5 & [34] \\
\hline Pleurotus pulmonaris & 25 & $20 \mathrm{mg} \mathrm{L}^{-1}$ & $\begin{array}{l}\text { DEA, DIA, DEDIA and 2-chloro-4-ethylamino-6- } \\
\text { (1-hydroxyisopropyl) amino-1,3,5 triazine }\end{array}$ & 50 & [28] \\
\hline Lentinula edodes & 30 & $10 \mu \mathrm{gL}^{-1}$ & U.M.* & 26 & [35] \\
\hline Agaricus subrufescens & 30 & $10 \mu \mathrm{gL}^{-1}$ & U.M.* & 35 & [35] \\
\hline P. ostreatus INCQS 40310 & 15 & $10 \mathrm{mg} \mathrm{L}^{-1}$ & DEA and DIA & 39 & $\begin{array}{c}\text { Present study; before factorial } \\
\text { design }\end{array}$ \\
\hline P. ostreatus INCQS 40310 & 15 & $10 \mathrm{mg} \mathrm{L}^{-1}$ & DIHA, DEDIA, DEHA, DIA and DEA & 71 & $\begin{array}{l}\text { Present study; fractional } \\
\text { factorial design }\left(2^{8-4}\right)\end{array}$ \\
\hline P. ostreatus INCQS 40310 & 10 & $10 \mathrm{mg} \mathrm{L}^{-1}$ & DIHA, DEDIA, DEHA, DIA and DEA & 90 & $\begin{array}{l}\text { Present study; full factorial } \\
\text { design }\left(3^{2}\right)\end{array}$ \\
\hline
\end{tabular}

Table 5: Studies on atrazine degradation mediated by fungi. Comparative description of experimental conditions and the metabolites obtained. 
Citation: Pereira PM, Sobral Teixeira RS, de Oliveira MAL, da Silva M, Ferreira-Leitão VS (2013) Optimized Atrazine Degradation by Pleurotus ostreatus INCQS 40310: an Alternative for Impact Reduction of Herbicides Used in Sugarcane Crops. J Microb Biochem Technol S12: 006. doi:10.4172/1948-5948.S12-006

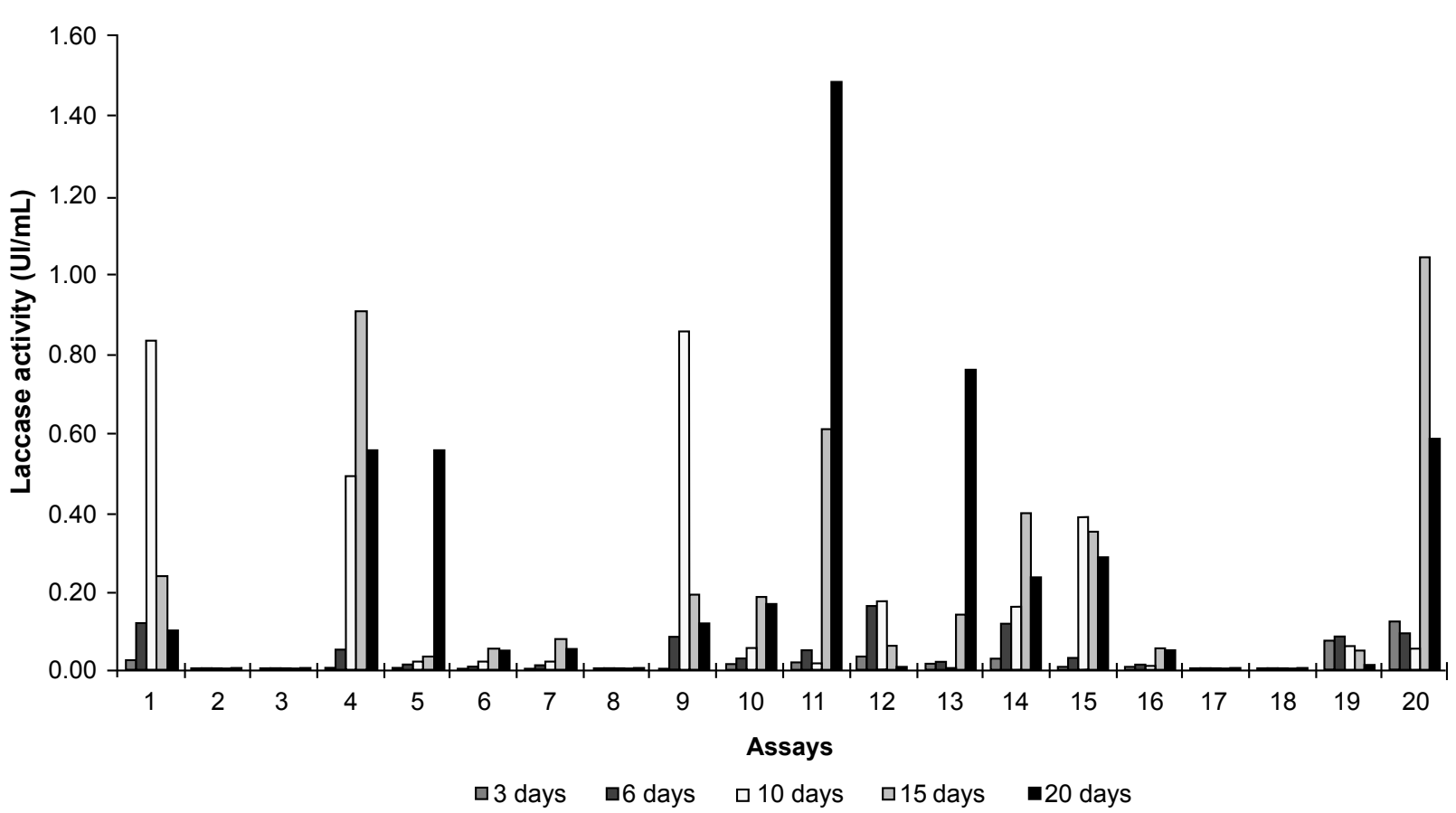

Figure 2: Laccase activity in all media studied in the $2_{\mathrm{IV}}{ }^{8-4}$ fractional factorial design $(3,6,10,15$ and 20 days).

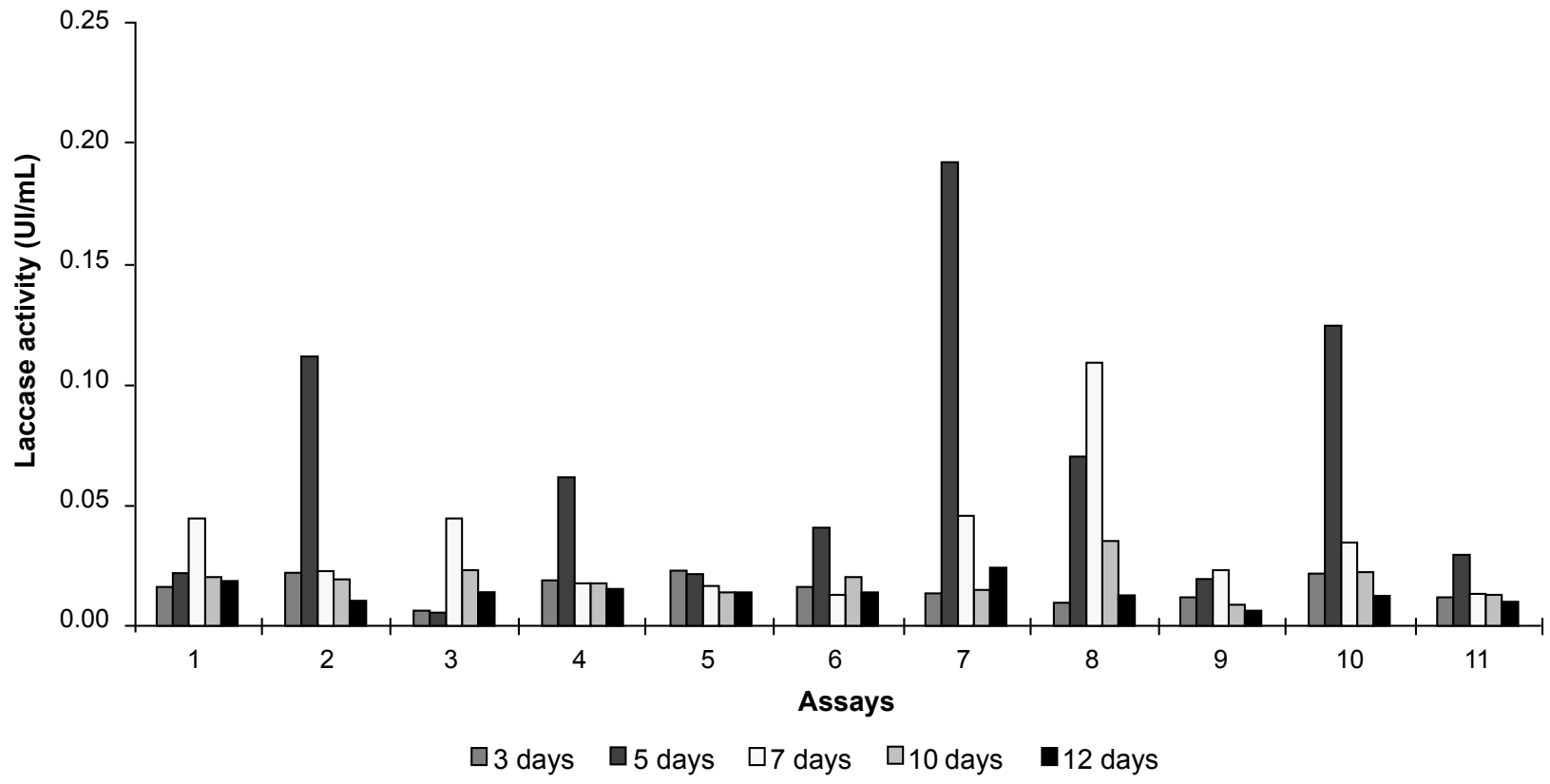

Figure 3: Laccase activity in all media studied in the $3^{2}$ full factorial design (3, 5, 7, 10 and 12 days).

the degradation of atrazine. Indeed, the significance of the $\mathrm{Fe}_{2} \mathrm{SO}_{4}$ in the culture medium revealed during this study that the degradation process could be directly related to cytochrome P450 enzymes, which are well-known hemeproteins.

\section{Conclusions}

The optimization strategy enabled the selection of a culture medium capable of promoting high atrazine degradation, $90.3 \%$ and $94.5 \%$, after 10 and 15 days, respectively, which increased atrazine degradation by a factor of 2.5 (39.0\% to $94.5 \%)$. Our results agreed with previous studies described in the literature in which dealkylated products appeared as the major metabolites produced during the initial mechanism of microbial degradation of chloro-s-triazines.

Although P. ostreatus INCQS 40310 was able to degrade atrazine 
Citation: Pereira PM, Sobral Teixeira RS, de Oliveira MAL, da Silva M, Ferreira-Leitão VS (2013) Optimized Atrazine Degradation by Pleurotus ostreatus INCQS 40310: an Alternative for Impact Reduction of Herbicides Used in Sugarcane Crops. J Microb Biochem Technol S12: 006. doi:10.4172/1948-5948.S12-006

and laccase was produced under certain conditions, it was not possible to correlate the production of this enzyme with atrazine degradation. Additionally, the significant presence of $\mathrm{Mn}$ in the optimized medium was not related to manganese peroxidase activity.

The results obtained in the optimization of the culture medium (salts of Fe and Mn as significant variables) suggested the involvement of other enzymes for atrazine degradation, such as P450 enzymes. The relationship between the involvement of extracellular/intracellular enzymes during atrazine degradation is now under investigation. Further work is necessary to clarify this question and the biochemistry of atrazine degradation by $P$. ostreatus INCQS 40310.

The present investigation demonstrates the high potential of the filamentous fungus $P$. ostreatus INCQS 40310 as a bioremediation agent. It is also important to mention that the use of factorial design was crucial for the improvement of the degradation levels.

\section{Acknowledgments}

The authors would like to thank the Brazilian National Council for Scientific and Technological Development, CNPq, the Carlos Chagas Filho Foundation, FAPER and FIOCRUZ (PAPES VI Project) for financial support.

The authors are thankful to the Federal University of Lavras, especially to the Edible Mushroom Laboratory, for providing the strain of Pleurotus ostreatus INCQS 40130

\section{References}

1. Dams RI (2006) Pesticidas: Usos e perigos à saúde e ao meio ambiente. Revista Saúde e Ambiente 7 .

2. SINDAG (2011) National Association of Industry of Agricultural Products for the Defense.

3. Companhia Nacional de Abastecimento (2012) Levantamentos de safras Conab.

4. de Armas ED, Monteiro RTR, Amâncio AV, Correa RML, Guercio MA (2005) Uso de agrotóxicos em cana-de-açúcar na bacia do rio Corumbataí e o risco de poluição hídrica. Quím Nova 28: 975-982.

5. ANVISA (2011) National Agency of Sanitary Surveillance. Monographs of pesticides.

6. Colla LM, Primaz AL, de Lima M, Bertolin TE, Costa JAV (2008) Isolamento e seleção de fungos para biorremediação a partir de solo contaminado com herbicidas triazínicos. Ciênc Agrotec 32: 809-813.

7. Mudhoo A, Garg VK (2011) Sorption, Transport and Transformation of atrazine in soils, minerals and composts: a review. Pedosphere 21: 11-25.

8. http://www.epa.gov/teach/chem_summ/Atrazine_summary.pdf

9. Scheunert I (1992) Transformation and degradation of pesticides in soil. In EBING, W. ed Terrestrial Behaviour of Pesticides. Springer verlag 25-75.

10. Hickey WJ, Fuster DJ, Lamar RT (1994) Transformation of atrazine in soil by Phanerochaete chrysosporium. Soil Biol Biochem 26: 1655 -1671.

11. Radosevich M, Traina SJ, Hao YL, Tuovinen OH (1995) Degradation and mineralization of atrazine by a soil bacterial isolate. Appl Environ Microbiol 61 297-302.

12. Mougin C, Laugero C, Asther M, Chaplain V (1996) Biotransformation of s-Triazine Herbicides and Related Degradation Products in Liquid Cultures by the White Rot Fungus Phanerochaete chrysosporium. Pesticide Science 49: 169-177.

13. Bennet JW, Wunch KG, Faison BD (2002) Use of fungi biodegradation. Manual of Environmental Microbiology, (Second Edition), ASM Press Washington, D.C 960-971.

14. Ueta J, Pereira NL, Shuhama IK, Cerdeira AL (1999) Biodegradação de herbicidas e biorremediação: microrganismos degradadores do herbicida atrazina. Biotecnologia 10: 10-13.

15. Mougin C, Laugero C, Asther M, Dubroca J, Frasse P, et al. (1994) Biotransformation of the Herbicide Atrazine by the White Rot Fungus Phanerochaete chrysosporium. Appl Environ Microbiol 60: 705-708.
16. Ferreira-Leitão VS, Bon EPS, Ferrara A (2008) Importância ambienta da biocatálise. In: Itamar Soares de Melo; João Lúcio de Azevedo. (org) Microbiologia Ambiental. (2ndedn), Jaguariúna Embrapa 185-198.

17. Balesteros MR (2009) Dissertação de mestrado. Universidade Federal de Juiz de Fora. Desenvolvimento e otimização de metodologia para análise de atrazina e seus produtos de degradação por cromatografia líquida de alta eficiência e eletroforese capilar.

18. Bergsten-Torralba LR, Nishikawa MM, Baptista DF, Magalhães DP, Da Silva M (2009) Decolorization of different textile dyes by Penicillium simplicissimum and toxicity evaluation after fungal treatment. Braz J Microbiol 40: 808-817.

19. Passarini MR, Rodrigues MV, da Silva M, Sette LD (2011) Marine-derived filamentous fungi and their potential application for polycyclic aromatic hydrocarbon bioremediation. Mar Pollut Bull 62: 364-370.

20. Teixeira RS, Pereira PM, Ferreira-Leitão VS (2010) Extraction and Application of Laccases from Shimeji Mushrooms (Pleurotus ostreatus) Residues in Decolourisation of Reactive Dyes and a Comparative Study Using Commercial Laccase from Aspergillus oryzae. Enzyme Res 2010: 905896.

21. da Silva M, Cerniglia CE, Pothuluri JV, Canhos VP, Esposito E (2003) Screening filamentous fungi isolated from estuarine sediments for the ability to oxidize polycyclic aromatic hydrocarbons. World Journal of Microbiology \& Biotechnology 19: 399-405

22. da Silva M, Esposito E, Moody JD, Canhos VP, Cerniglia CE (2004) Metabolism of aromatic hydrocarbons by the filamentous fungus Cyclothyrium sp. Chemosphere 57: 943-952.

23. Marcial J, Barrios-Gonzalez J, Tomasini A (2006) Effect of medium composition on pentachlorophenol removal by Amylomyces rouxii in solid state culture. Process Biochemistry 41: 496-500.

24. Purnomo AS, Kamei I, Kondo R (2008) Degradation of 1,1,1-trichloro-2,2-bis (4-chlorophenyl) ethane (DDT) by brown-rot fungi. J Biosci Bioeng 105: 614 621.

25. Krügener S, Schaper C, Krings U, Berger RG (2009) Pleurotus species convert monoterpenes to furanoterpenoids through 1,4-endoperoxides. Bioresour Technol 100: 2855-2860.

26. Trovaslet-Leroy M, Jolivalt C, Froment MT, Brasme B, Lefebvre B, et al (2010) Application of laccase-mediator system (LMS) for the degradation of organophosphorus compounds. Chem Biol Interact 187: 393-396.

27. Rajarathnam S, Shashireka MN, Bano Z (1992) Biopotentialities of the basidiomacromycetes. Adv Appl Microbiol 37: 233-361

28. Masaphy S, Levanon D, Vaya J, Henis Y (1993) Isolation and Characterization of a Novel Atrazine Metabolite Produced by the Fungus Pleurotus pulmonarius, 2-Chloro-4-Ethylamino-6-(1-Hydroxyisopropyl)Amino-1,3,5-Triazine. Appl Environ Microbiol 59: 4342-4346.

29. Pereira PM (2011) Dissertação de mestrado. Fundação Oswaldo Cruz, Instituto Nacional de Controle de Qualidade em Saúde. Avaliação do potencial de fungos na degradação do herbicida atrazina.

30. Gorbatova ON, Koroleva OV, Landesman EO, Stepanova EV, Zherdev AV (2006) [Increase of the detoxification potential of basidiomycetes by induction of laccase biosynthesis]. Prikl Biokhim Mikrobiol 42: 468-474.

31. Niku-Paavola ML, Raaska L, Itävaara M (1990) Detection of white-rot fungi by a non-toxic stain. Mycological Research 94: 27-31.

32. Kuwahara M, Glenn JK, Morgan MA, Gold MH (1984) Separation and characterization of two extracellular $\mathrm{H} 2 \mathrm{O} 2$-dependent oxidases from ligninolytic cultures of Phanerochaste chrysosporium. FEBS Lett 169: 247-250.

33. Tien M, Kirk TK (1984) Lignin-degrading enzyme from Phanerochaete chrysosporium: Purification, characterization, and catalytic properties of a unique $\mathrm{H}_{2} \mathrm{O}_{2}$-requiring oxygenase. Proc Natl Acad Sci U S A 81: 2280-2284

34. Ralston-Hooper K, Hardy J, Hahn L, Ochoa-Acuña H, Lee LS, et al. (2009) Acute and chronic toxicity of atrazine and its metabolites deethylatrazine and deisopropylatrazine on aquatic organisms. Ecotoxicology 18: 899-905

35. Pugh KC (1994) Toxicity and physical properties of atrazine and its degradatin products: A lititerature survey. Waste Management and Remediation Environmental Research Center Muscle Shoals 4-19.

36. Cook AM (1987) Biodegradation of s-triazine xenobiotics. FEMS Microbiol Rev 46: 93-116. 
Citation: Pereira PM, Sobral Teixeira RS, de Oliveira MAL, da Silva M, Ferreira-Leitão VS (2013) Optimized Atrazine Degradation by Pleurotus ostreatus INCQS 40310: an Alternative for Impact Reduction of Herbicides Used in Sugarcane Crops. J Microb Biochem Technol S12: 006. doi:10.4172/1948-5948.S12-006

37. Wolf DC, Martin JP (1975) Microbial decomposition of ring-4C atrazine, cyanuric acid and 2-chloro-4,6-diamino-s-triazine. Journal of Environmental Quality 4: 134-139.

38. Bending GD, Friloux M, Walker A (2002) Degradation of contrasting pesticides by white rot fungi and its relationship with ligninolytic potential. FEMS Microbiol Lett 212: 59-63.

39. Ribas LC, de Mendonça MM, Camelini CM, Soares CH (2009) Use of spent mushroom substrates from Agaricus subrufescens (syn. A. blazei, A brasiliensis) and Lentinula edodes productions in the enrichment of a soilbased potting media for lettuce (Lactuca sativa) cultivation: Growth promotion and soil bioremediation. Bioresour Technol 100: 4750-4757.
Citation: Pereira PM, Sobral Teixeira RS, de Oliveira MAL, da Silva M, FerreiraLeitão VS (2013) Optimized Atrazine Degradation by Pleurotus ostreatus INCQS 40310: an Alternative for Impact Reduction of Herbicides Used in Sugarcane Crops. J Microb Biochem Technol S12: 006. doi:10.4172/19485948.S12-006

This article was originally published in a special issue, Bioresource Technology handled by Editor(s). Dr. Dr. Tingyue Gu, Ohio University, USA; Prof. Minghua Zhou, Nankai University, China
40. Wesenberg D, Kyriakides I, Agathos SN (2003) White-rot fungi and their enzymes for the treatment of industrial dye effluents. Biotechnol Adv 22: 161 187.

41. Hiratsuka N, Wariishi H, Tanaka H (2001) Degradation of diphenyl ethe herbicides by the lignin-degrading basidiomycete Coriolus versicolor. App Microbiol Biotechnol 57: 563-571.

42. Bastos AC, Magan N (2009) Trametes versicolor: Potential for atrazine bioremediation in calcareous clay soil, under low water availability conditions. Int Biodeter Biodegrad 63: 389-394.

\section{Submit your next manuscript and get advantages of OMICS Group submissions}

Unique features:

User friendly/feasible website-translation of your paper to 50 world's leading languages

Audio Version of published paper

Digital articles to share and explore

Special features:

250 Open Access Journals

20,000 editorial team

21 days rapid review process

Quality and quick editorial, review and publication processing

Indexing at PubMed (partial), Scopus, DOAJ, EBSCO, Index Copernicus and Google Scholar etc

Sharing Option: Social Networking Enabled

- Authors, Reviewers and Editors rewarded with online Scientific Credits

Better discount for your subsequent articles

Submit your manuscript at: http://www.editorialmanager.com/imb 